\title{
КОМПЕТЕНЦИЯ ПРАВИТЕЛЬСТВА В СФЕРЕ БЮДЖЕТНОЙ И ФИНАНСОВОЙ ПОЛИТИКИ (НОВЕЛЛЫ ЗАКОНОДАТЕЛЬСТВА)
}

\author{
(c) 2020 Кобзарь-Фролова Маргарита Николаевна
}

доктор юридических наук, профессор

главный научный сотрудник сектора административного права и процесса

Институт государства и права РАН, Россия, Москва

(c) 2020 Щукина Татьяна Владимировна

доктор юридических наук, доцент

ведущий научный сотрудник сектора административного права и процесса

Институт государства и права РАН, Россия, Москва

Произошедшие в стране в социально-политической сфере изменения, опосредовали изменения в сфере экономики. В первую очередь это относится к вопросам компетенции органов, осуществляющих регулирование отношений в сфере бюджета и финансов. Правительство Российской Федерации - орган, на который конституцией возложена обязанность проведения бюджетной, финансовой налоговой политики, а также обязанность составления и исполнения бюджета. Исследуя элементы компетенции Правительства, авторы приходят к выводу о том, что ранее Правительство было наделено правом проводить в стране бюджетную и финансовую политику. После поправок, внесенных в Конституцию - это обязанность Правительства. За неисполнение этой обязанности Правительство несет ответственность.

Ключевые слова: финансовая политика, бюджетная политика, Правительство, полномочия, компетенция, бюджетная сфера, сфера финансов, экономика, обеспечение исполнения законодательства, ответственность

Июль 2020 года был отмечен тем, что в России произошло важное историческое событие. После публично проведенного обсуждения и общероссийского голосования в Конституцию Российской Федерации были внесены изменения [1], которые неизменно найдут свое отражение в политической и социальной жизни страны. Эти изменения были направлены на создание условий для укрепления российской государственности, устойчивый экономический рост страны, повышение благосостояния граждан, взаимное доверие государства и общества, обеспечение конституционных гарантий граждан и их объединений и многое другое [2].

Как установил в своем Заключении от 16.03.2020 № 1-3 Конституционный суд Российской Федерации [3] изменения в отношении элементов конституционного статуса Правительства Российской Федерации установлены статьями 110-113, 115-117, а вопросы компетенции статьей 114 Конституции. Они согласуются с местом Правительства Российской Федерации в системе органов государственной власти, характером его функций (направлениями деятельно- сти), и порядком взаимоотношений с иными органами государственной власти на федеральном и региональном уровнях.

Правительство Российской Федерации высший орган исполнительной власти, обладающий общей компетенцией и регулирующий отношения во всех отраслях и сферах общественной жизни. Объем прав и обязанностей (компетенция) Правительства Российской Федерации в сфере бюджета, финансов и иных сферах экономики детализированы в нормах Федерального конституционного закона № 2-ФКЗ от 17 декабря 1997 года «О Правительстве Российской Федерации».

Вместе с указанным, важно отметить, что вступление в силу Закона о поправке Конституции опосредовало необходимость изменения действующего законодательства. По инициативе Президента Российской Федерации подготовлен пакет проектов законов. Среди них Проект № 1024645-7 Федерального конституционного закона «О Правительстве Российской Федерации» [4]. Нормы Проекта № 1024645-7 определяют статус Правительства РФ, организационно- 
правовые основы его формирования и деятельности. Этими же нормами предусмотрено обеспечение согласованного функционирования и взаимодействия Правительства и иных органов, входящих в единую систему публичной власти.

Конституцией возложено на Правительство руководство практически всеми отраслями экономики, социально-культурной и административно-политической сферами, относящимися к ведению Федерации и совместному ведению Федерации и ее субъектов.

Закрепляя компетенцию Правительства Российской Федерации, в нормах Конституции Российской Федерации, особо подчеркнута ответственность Правительства за принимаемые решения и его роль в обеспечении исполнения законодательства Российской Федерации (глава 6 Конституции).

Правительство ответственно за разработку и предоставление в Государственную Думу федерального бюджета и обеспечивает его исполнение.

Термин «финансовая политика», как одно из важнейших направлений деятельности Правительства Российской Федерации, законодательного закрепления не имеет. Между тем все намечаемые стратегические цели и ориентиры должны быть обеспечены финансовыми ресурсами. Государство не может получать своего развития, а Правительство не может решать поставленные задачи, не аккумулируя финансовые средства, и, не создавая целевые денежные фонды.

Несомненно, финансовая политика - важнейшая составная часть правовой политики государства. Нам представляется, что финансовая политика Российской Федерации - это целенаправленная деятельность специально уполномоченных органов государства, связанная с мобилизацией финансовых ресурсов, их распределением, перераспределением и использованием для выполнения государством своих основных задач и функций в области социальноэкономического развития, обеспечения безопасности, обороны, защиты и др.

Финансовая политика - многогранна, как и финансовая деятельность государства. Важнейшими составляющими финансовой политики российского государства являются: бюджетная, налоговая, кредитно-денежная политика, политика в области валютного регулирования, рынка ценных бумаг и др. [5]

Финансовая политика не может быть самостоятельной и независимой [6]. Направления финансовой политики, как производной от общегосударственной политики определяют: послания Президента Российской Федерации Федеральному Собранию Российской Федерации; прогнозы социально-экономического развития страны; бюджетные прогнозы на долгосрочный период; стратегические планы и программы социально-экономического развития страны; государственные (муниципальные) программы основных направлений бюджетной, налоговой и таможенно-тарифной политики Российской Федерации; направления единой государственной денежно-кредитной политики и др.

Задачи и функции по выработке единой государственной финансовой, кредитной, денежной политики, нормативно-правовому регулированию в финансовой сфере, включая бюджетную, налоговую, валютную, банковскую деятельность, сферу финансовых рынков, государственного долга, финансового обеспечения государственной службы, страхованию (в т.ч. обязательного пенсионного страхования) и другие на федеральном уровне нормативно закреплены за Министерством финансов Российской Федерации. Правительство, как регулирующий орган, координирует деятельность финансовых органов, вырабатывает основные (стратегические) направления политики в сфере бюджета и финансов, осуществляет контроль за их деятельностью, мониторит исполнение отданных поручений и др.

Наиболее детально полномочия Правительства Российской Федерации в сфере бюджета отражены в действующем Бюджетном кодексе Российской Федерации (далее - БК РФ). Бюджет Федерации - это основанный на экономических отношениях и государственном устройстве Российской Федерации основной финансовый план, согласно которому живет и развивается страна и все ее отрасли. Бюджет - это форма образования и расходования денежных средств, предназначенных для финансового обеспечения задач и функций государства и местного самоуправления.

Правительство Российской Федерации является одним из участников бюджетного процесса на федеральном уровне. Составление проекта бюджета Федерации - исключительная прерогатива (а теперь и обязанность) Правительства 
Российской Федерации. Непосредственное составление проекта федерального бюджета осуществляют Министерство финансов Российской Федерации (далее - Минфин России), органы управления государственными внебюджетными фондами, финансовые органы субъектов Российской Федерации и муниципальных образований.

Правительство Российской Федерации вправе издавать нормативные акты, регулирующие бюджетные правоотношения. Такие акты принимаются и издаются в форме постановлений. Акты Правительства, не имеющие нормативного содержания, - распоряжения. Они принимаются относительно вопросов оперативного и иного текущего характера. При этом Правительство ответственно за обеспечение исполнения принятых актов. Кроме указанного Правительство РФ обязано направлять в палаты Федерального Собрания информацию о ходе разработки и предполагаемых сроках принятия нормативных правовых актов, предусмотренных федеральными законами.

Правительство Российской Федерации организует работу по составлению проекта федерального бюджета, возлагает на федеральные органы исполнительной власти, уполномоченные в сфере финансов ответственность по исполнению федерального бюджета, а также функции по исполнению бюджетов государственных внебюджетных фондов Российской Федерации, бюджетов субъектов Российской Федерации, бюджетов территориальных государственных внебюджетных фондов и местных бюджетов [7].

Правительство Российской Федерации устанавливает порядок и сроки составления проекта федерального бюджета и проектов бюджетов государственных внебюджетных фондов Российской Федерации.

Правительство представляет Государственной Думе ежегодные отчеты о результатах своей деятельности, в том числе отчет об исполнении федерального бюджета и отчеты по вопросам, поставленным Государственной Думой.

Орган, ответственный за составление бюджетной отчетности, ведение учета операций по кассовому исполнению федерального бюджета,- Федеральное казначейство (федеральная служба, подведомственная Минфину России). Федеральное казначейство также составляет и представляет в Минфин России отчет об исполнении консолидированного бюджета Россий- ской Федерации и бюджетов государственных внебюджетных фондов. Отчет об исполнении федерального бюджета составляется за первый квартал, полугодие и девять месяцев текущего финансового года.

Отчет утверждается Правительством и направляется в Государственную Думу, Совет Федерации и Счетную палату Российской Федерации. Годовой отчет об исполнении федерального бюджета подлежит рассмотрению Государственной Думой и утверждению федеральным законом. Таким образом, повышается взаимная ответственность Правительства и Государственной Думы. Внешняя проверка годового отчета об исполнении федерального бюджета, до его рассмотрения в Государственной Думе, осуществляется Счетной палатой Российской Федерации в порядке, установленном БК РФ.

На Правительство Конституцией возложена обязанность по обеспечению исполнения бюджета. Орган, ответственный за организацию исполнения бюджета - Минфин России. По смыслу и содержанию норм БК РФ бюджет исполняется отдельно по доходам и отдельно по расходам, в соответствии с правилами, закрепленными в БК РФ. Бюджет исполняется на основе единства кассы и подведомственности расходов. Кассовое обслуживание исполнения бюджетов бюджетной системы Российской Федерации осуществляется Федеральным Казначейством.

Правительство Российской Федерации обеспечивает проведение финансового контроля и мониторинга на всех этапах исполнения бюджета. Правила и процедуры проведения мероприятий финансового контроля и мониторинга разрабатывает и утверждает, посредством принятия административных регламентов, Минфин России. Органами государственного финансового контроля являются Минфин России и подведомственные Минфину - Федеральное казначейство, Федеральная налоговая служба, Федеральная таможенная служба и др. Полномочия в области финансового контроля имеет Счетная палата Российской Федерации.

Государственная Дума при рассмотрении отчета Правительства об исполнении федерального бюджета заслушивает: доклад министра финансов об исполнении федерального бюджета и доклад Председателя Счетной палаты о заключении Счетной палаты Российской Федерации на годовой отчет об исполнении федерального бюджета. Таким образом, Государственная Дума 
реализует свои контрольные функции в отношении полномочий Правительства в сфере разработки бюджета и обеспечении его исполнения. Свои доклады с анализом рассмотренных в течение отчетного финансового года дел, связанных с бюджетными спорами и нарушениями бюджетного законодательства Российской Федерации вправе представить в Государственную Думу Генеральный прокурор Российской Федерации, Председатель Конституционного Суда Российской Федерации, Председатель Верховного Суда Российской Федерации. Государственная Дума по результатам рассмотрения годового отчета об исполнении федерального бюджета принимает либо отклоняет федеральный закон об исполнении федерального бюджета. В случае отклонения Государственной Думой федерального закона об исполнении федерального бюджета он возвращается в Правительство для устранения фактов недостоверного или неполного отражения отчетных данных.

Разработка и представление Государственной Думе федерального бюджета и обеспечение его исполнения, только часть полномочий Правительства в сфере финансов. Согласно пункта «б» части 1 статьи 114, Правительство обеспечивает проведение в Российской Федерации единой финансовой, кредитной и денежной политики.

Полномочия Правительства в сфере бюджета, финансовой, кредитной, денежной политики определены Конституцией в качестве первостепенных в пунктах «а» и «б». Указанная сфера ответственности Правительства Российской Фе- дерации детализирована в статье 15 Федерального конституционного закона № 2-ФКЗ от 17 декабря 1997 года «О Правительстве Российской Федерации». Данной статьей к полномочиям Правительства в части определения политики в рассматриваемых сферах отнесены: разработка и реализация налоговой политики; совершенствование бюджетной системы; принятие мер по регулированию рынка ценных бумаг; управление государственным внутренним и внешним долгом Российской Федерации; валютное регулирование и валютный контроль; руководство валютно-финансовой деятельностью в отношениях Российской Федерации с иностранными государствами; проведение единой политики цен и др.

Таким образом, можно сделать вывод о том, что важнейшей новеллой законодательства в части компетенции Правительства в области бюджета и финансов связаны с возложением на Правительство обязанности обеспечить исполнение законодательства в указанных областях и несением ответственности за проводимую в этих сферах политику.

Обязанности, возложенные Конституцией на Правительство в области проведения единой финансовой, кредитной и денежной политики, (пункты «а» и «б» части 1 статьи 114), тесным образом связаны с независимостью страны на международной арене, обеспечением государственного суверенитета и единства экономического пространства на всей территории, созданием условий достойной жизни и свободного развития человека и гражданина, и др.

\section{Библиографический список}

1. О совершенствовании регулирования отдельных вопросов организации и функционирования публичной власти: закон Российской Федерации о поправке к Конституции Российской Федерации от 14 марта 2020 года № 1-ФКЗ // Собр. законодательства Рос. Федерации. 2020. № 11. Ст. 1416.

2. О соответствии положениям глав 1, 2 и 9 Конституции Российской Федерации не вступивших в силу положений Закона Российской Федерации о поправке к Конституции Российской Федерации «О совершенствовании регулирования отдельных вопросов организации и функционирования публичной власти», а также о соответствии Конституции Российской Федерации порядка вступления в силу статьи 1 данного Закона в связи с запросом Президента Российской Федерации: Заключение Конституционного Суда РФ от 16 марта 2020 г. № 1-3 // Собр. законодательства Рос. Федерации. 2020. № 12. Ст. 1855.

3. Там же.

4. Проект № 1024645-7 Федерального конституционного закона «О Правительстве Российской Федерации». Режим доступа: https://sozd.duma.gov.ru/ по состоянию на 22.09.2020

5. Кобзарь-Фролова М.Н. Развитие финансово-правого механизма бюджетной, налоговой, таможенной политики Российской Федерации // Финансовое право. 2016. № 4. С.11-13; 
6. Кобзарь-Фролова М.Н. Тенденции и приоритеты бюджетной, налоговой, таможенной политики Российской Федерации в условиях экономических вызовов // Вопросы правоведения. 2015. № 6. С.195-207

7. Проект № 1024645-7 Федерального конституционного закона «О Правительстве Российской Федерации». Режим доступа: https://sozd.duma.gov.ru/ по состоянию на 22.09.2020 